\title{
Host-Guest Extraction of Heavy Metal Ions with $p$-t-Butylcalix[8]arene from Ammonia or Amine Solutions
}

\author{
Md. Hasan Zahir ${ }^{D},{ }^{1}$ Shakhawat Chowdhury, ${ }^{2}$ \\ Md. Abdul Aziz, ${ }^{3}$ and Mohammad Mizanur Rahman ${ }^{4}$ \\ ${ }^{1}$ Center of Research Excellence in Renewable Energy, Research Institute, King Fahd University of Petroleum and Minerals, \\ Dhahran 31261, Saudi Arabia \\ ${ }^{2}$ Department of Civil and Environmental Engineering, Water Research Group, King Fahd University of Petroleum and Minerals, \\ Dhahran 31261, Saudi Arabia \\ ${ }^{3}$ Center of Research Excellence in Nanotechnology, King Fahd University of Petroleum and Minerals, Dhahran 31261, Saudi Arabia \\ ${ }^{4}$ Center of Research Excellence in Corrosion, King Fahd University of Petroleum and Minerals, Dhahran 31261, Saudi Arabia
}

Correspondence should be addressed to Md. Hasan Zahir; hzahir@kfupm.edu.sa

Received 25 March 2018; Revised 4 June 2018; Accepted 21 June 2018; Published 11 July 2018

Academic Editor: Seyyed E. Moradi

Copyright (C) $2018 \mathrm{Md}$. Hasan Zahir et al. This is an open access article distributed under the Creative Commons Attribution License, which permits unrestricted use, distribution, and reproduction in any medium, provided the original work is properly cited.

\begin{abstract}
The capacities of the $p$-t-butylcalix[8]arene (abbreviated as $\mathrm{H}_{8} \mathrm{~L}$ ) host to extract toxic divalent heavy metal ions and silver from aqueous solution phases containing ammonia or ethylene diamine to an organic phase (nitrobenzene, dichloromethane, or chloroform) were carried out. When the metal ions were extracted from an aqueous ammonia solution, the metal ion selectivity for extraction was found to decrease in the order $\mathrm{Cd}^{2+}>\mathrm{Ni}^{2+}>\mathrm{Cu}^{2+}>\mathrm{Ag}^{+}>\mathrm{Co}^{2+}>\mathrm{Zn}^{2+}$. When the aqueous phase contained ethylene diamine, excellent extraction efficiencies of $97 \%$ and $90 \%$ were observed for the heavy metal ions $\mathrm{Cu}^{2+}$ and $\mathrm{Cd}^{2+}$, respectively. Under the same conditions the extraction of octahedral type metal ions, namely, $\mathrm{Co}^{2+}$ and $\mathrm{Ni}^{2+}$, was suppressed. The extraction of transition metal cations by $\mathrm{H}_{8} \mathrm{~L}$ in ammonia and/or amine was found to be $\mathrm{pH}$ dependent. Detailed analysis of extraction behavior was investigated by slope analysis, the continuous variation method, and by loading tests.
\end{abstract}

\section{Introduction}

Host-guest chemistry has attracted great attention in the field of separation and/or extraction of alkaline, rare earth, and divalent heavy metal ions with calixarenes and their ester derivatives. Calixarenes have unusual capabilities to identify and distinguish between different ions and molecules, which makes them appropriate to use as specific receptors [13]. Calixarenes are macrocyclic phenolic oligomers with phenolic hydroxyl groups, which are able to coordinate the metal ions very tightly. As a result, the aromatic phenolic rings can form a cavity to integrate the guest metal ion. Recently, Yusof et al. reported that the heavy metal ions could be included into the host calix[4] resorcinarenes cavity in water-chloroform extraction systems $[4,5]$. Calix [6] arenes can be also modified with a carboxylic acid as host in the host-guest extraction of immunoglobulin G (IgG) [6]. In fact, a precise affinity can be created for specific ions and/or molecules by modification the hydroxyl functional group and/or by creating a new cavity size [7]. In calixarenes, the cavity size, position and type of donor groups, and molecular flexibility lead to their high potential for the complexation and extraction of metal ions. Ludwig et al. reported the impact of calixarenes in analytical chemistry and chemical separation technology in a review article [8].

The modification of $p$ - $t$-butylcalix $[n]$ arenes $(n=4,6$, 8) has been extensively investigated, facilitating the synthesis of a variety of host compounds with varying shapes and sizes that have been shown to be valuable in ion or molecular recognition studies $[9,10]$. In particular, $p$ - $t$ butylcalix [8] arene (abbreviated as $\mathrm{H}_{8} \mathrm{~L}$ ) has shown interesting complexing properties towards $\mathrm{C}_{60}$-fullerene, cesium, or 
strontium cations. This means that new synthetic routes with different functionalized derivatives of $\mathrm{H}_{8} \mathrm{~L}$ could be more versatile [11].

$\mathrm{H}_{8} \mathrm{~L}$ can form host-guest complexes through hydrophobic and $\pi-\pi$ interactions within the cavities of $\pi$-donors composed of benzene rings, polycyclic aromatic hydrocarbons, anthraquinones, phenol regioisomers, and fullerene $\pi$ systems, due to their considerable electron affinity [12]. From a coordination standpoint, the reaction of $\mathrm{H}_{8} \mathrm{~L}$ with metal ions is more complex than that of $\mathrm{H}_{6} \mathrm{~L}$; however, already few calix [8]crowns have been reported in the open literature $[13,14]$. Derivatives of calix[n]arenes could be formed by inserting binding groups such as amines and/or alcohols into the upper and lower rim positions of the calixarene moiety [15]. It has been reported that proton transfer from an $\mathrm{OH}$-group of the parent calixarene to an amine might occur during the reaction period, eventually resulting in a new compound from the association and inclusion of the amine into the cavity of the calixarene [16]. Finally, the abovementioned studies have established that calixarenes can effectively react with most metal ions and the new organometallic compounds can be obtained in good yields $[8-10,17]$.

$\mathrm{H}_{8} \mathrm{~L}$ has been utilized in the separation of metallic cations [18, 19], the extraction of methyl esters of some amino-acids [20], uranium (VI) preconcentration [21], lanthanide complexes [22], and molecular recognition of 1,5diaminoantraquinone [23]. Erdemir et al. investigated the extraction abilities of carboxylic acid and methyl ester derivatives of $p$-t-butylcalix[n]arenes $(n=6,8)$ for carcinogenic aromatic amines [24]. Other calixarenes and their derivatives have been utilized in the fields of complexation, separation, electroanalysis, spectroscopy, and chemometrics [25].

A larger ligand, i.e., $\mathrm{H}_{8} \mathrm{~L}$, can act as a ditopic receptor for lanthanide and transition metal ions [26] and hence in principle may bind to a single metal ion in various ways. It is important to mention that solvent extraction of transition metal ions, particularly toxic metal ions, using $\mathrm{H}_{8} \mathrm{~L}$ alone has scarcely been reported in the open literature. Makrlik et al. studied the liquid-liquid extraction of $\mathrm{Eu}^{3+}$ trifluoromethanesulfonate into nitrobenzene in the presence of $\mathrm{H}_{6} \mathrm{~L}$ and $\mathrm{H}_{8} \mathrm{~L}$ [27]. Sansone et al. reported the separation of $\mathrm{An}^{3+} / \mathrm{Ln}^{3+}$ from radioactive waste using $\mathrm{CMPO}$ (carbamoylmethyl-phosphine oxide) substituted $\mathrm{H}_{6} \mathrm{~L}$ and $\mathrm{H}_{8} \mathrm{~L}$ [28]. Gutsche et al. synthesized aminocalixarenes complexes of $\mathrm{Ni}^{2+}, \mathrm{Cu}^{2+}, \mathrm{Pd}^{2+}, \mathrm{Co}^{2+}$, and $\mathrm{Fe}^{2+}$ and determined their spectral and chemical characteristics [10]. Their findings indicated that metal-aminocalixarenes are more flexible than had previously been thought. It has also been reported that $\mathrm{H}_{8} \mathrm{~L}$ can be combined into a polymeric medium to produce a material that shows a high sorption ability towards transition metal ions $\left(\mathrm{Cu}^{2+}, \mathrm{Fe}^{2+}, \mathrm{Zn}^{2+}, \mathrm{Ni}^{2+}, \mathrm{Co}^{2+}, \mathrm{Cd}^{2+}\right.$, and $\left.\mathrm{Pb}^{2+}\right)$ in aqueous solution [29]. The authors also performed research on the extraction behavior of transition metal ions with $\mathrm{H}_{4} \mathrm{~L}$ and $\mathrm{H}_{6} \mathrm{~L}[30,31]$.

An effective extractant with high selectivity for metal ions is in high demand for analytical applications, recycling of resources, and waste treatment purposes. Heavy metals such as lead $(\mathrm{Pb})$, copper $(\mathrm{Cu})$, and nickel $(\mathrm{Ni})$ are harmful to humans. Obviously, the harmful impact of some ions, for example, $\mathrm{Cd}^{2+}$ and $\mathrm{As}^{2+}$, is of great concern in such research. $\mathrm{Cd}^{2+}$ is one of the most toxic elements for humans. At high concentrations, it causes various debilitating conditions such as painful bone disease, bone marrow disorders, kidney problems, and "Itaiitai" or "ouch-ouch" disease [32]. However, calixarene derivatives may be useful binders for these cations.

In this study, $\mathrm{H}_{8} \mathrm{~L}$ has been investigated as host extractant for divalent heavy metal ions and silver from ammonia and amine solutions into various types of organic solvents. We also synthesized $\mathrm{H}_{8} \mathrm{~L}$ ethyl ester derivatives and the extraction behavior of transition metal cations from aqueous solution was also investigated.

\section{Experimental Section}

2.1. Materials. $\mathrm{H}_{8} \mathrm{~L}$ was purchased from the Sigma Aldrich Chemical Company, USA. All transition metal nitrate solutions were prepared according to the method in $[30,31]$. Other reagents such as chloroform, dichloromethane and nitrobenzene, and ethanol were purchased from Carlo Erba Reagents, France. Ammonia, ethylenediamine and trimethylene diamine, ethyl bromoacetate, $\mathrm{NaH}$, and THF/DMF were bought from Acros Organic, Belgium. The water was deionized. All the remaining reagents were as pure as is commercially available. Stock solutions were standardized by potentiometric and EDTA titrations. Other metal salts were guaranteed to be reagent grade.

2.2. Extraction Procedure. The hosts $\mathrm{H}_{8} \mathrm{~L}$ and $\mathrm{H}_{8} \mathrm{~L}$-ester were prepared by dissolving the appropriate amount in various organic solvents followed by the dilution, typically to $1 \times 10^{-4}$ $\mathrm{M}$ working solution; aqueous solutions of metal solutions were made from analytical purity nitrates of $\mathrm{Cd}^{2+}, \mathrm{Ni}^{2+}$, $\mathrm{Cu}^{2+}, \mathrm{Ag}^{2+}, \mathrm{Co}^{2+}$, and $\mathrm{Zn}^{2+}$. Extraction experiments were typically performed by equilibrating $8 \mathrm{~mL}$ of a $5 \times 10^{-5}$ $\mathrm{M}$ solution of the metal ions, $1 \mathrm{ml}$ succinic acid (0.01M), and $1 \mathrm{~mL}$ of a buffer solution with $10 \mathrm{~mL}$ of a $5 \times 10^{-4}$ $M$ solution of the $\mathrm{H}_{8} \mathrm{~L}$ in 1,2-dichloroethane. The mixture was placed in a stoppered $50 \mathrm{~mL}$ glass tube at a volume ratio of 10:10 $\mathrm{mL}$ (organic phase to aqueous phase). The $\mathrm{pH}$ was adjusted by three types of buffer solution: $\mathrm{CH}_{3} \mathrm{COOH}-$ $\mathrm{CH}_{3} \mathrm{COONa}$ (acidic region), $\mathrm{H}_{3} \mathrm{BO}_{3}-\mathrm{NaOH}$ (neutral), and $\mathrm{NH}_{3}-\mathrm{NH}_{4} \mathrm{Cl}$ (alkali). In the case of $\mathrm{H}_{8} \mathrm{~L}$-ester extractant, picric acid $\left[2.5 \times 10^{-5} \mathrm{M}\right]$ was used as the counter anion. The extraction equilibrium was attained within $40 \mathrm{~min}$ of shaking with nitrobenzene; the extraction into chloroform reached equilibrium within $20 \mathrm{~h}$ of shaking. Therefore, the shaking time was fixed at $2 \mathrm{~h}$ for nitrobenzene and at $20 \mathrm{~h}$ for chloroform. The extractability was not affected by further shaking, indicating that the equilibrium was attained within $12 \mathrm{~h}$. All the experiments were performed in presence of succinic acid to avoid emulsification during the extraction process. The distribution experiments were performed at room temperature.

Before shaking, the samples were left standing in the water bath at $25^{\circ} \mathrm{C}$ for $15 \mathrm{~min}$ to ensure that the extraction solutions were maintained at the same temperature. Then, 
a shaker at 200 stroke $\min ^{-1}$ at $25.0 \pm 0.1^{\circ} \mathrm{C}$ mixed the two phases; a shaking time of $12 \mathrm{~h}$ was sufficient to reach the extraction equilibrium. After shaking, the two phases were centrifuged at $2000 \mathrm{rpm}$. for $10 \mathrm{~min}$, which was sufficient for complete separation. Before the measurement, the $\mathrm{pH}$ of the aqueous and organic phases was adjusted to 2.5 using $5 \mathrm{M}$ $\mathrm{HNO}_{3}$ and $3 \mathrm{M} \mathrm{LiOH}$. The amount of extracted metal ions was calculated from the difference between the metal concentrations in the aqueous phase before and after the equilibration. The concentration of the metal ion in the organic phase was determined by the back-extraction method; 5 $\mathrm{cm}^{3}$ of the organic phase was transferred into another glassstoppered tube and shaken with $4 \mathrm{M}$ hydrochloric acid. After phase separation, the equilibrium concentrations of metal cations in the aqueous phase were measured by an inductively coupled plasma atomic emission spectrometer (Seiko model SPS 1200AR). The equilibrium $\mathrm{pH}$ in the aqueous solutions was measured by a pH meter (Beckmann model ø45).

The extractability $(\mathrm{Ex} \%)$ was determined from the decrease in the metal concentration in the aqueous phase:

$$
\mathrm{Ex} \%=\left\{\frac{\left.(\text { Metal })]_{\text {blank }}-[\text { Metal }]_{\text {water }}\right)}{(\text { Metal })]_{\text {blank }}}\right\} \times 100,
$$

where $[\text { Metal }]_{\text {blank }}$ and $[\text { Metal }]_{\text {water }}$ denote the metal concentrations in the aqueous phase after extraction with nitrobenzene and with the nitrobenzene solution containing extractants, respectively, and $[\text { Metal }]_{\text {or }}$ denotes the metal concentration extracted into the organic phase.

2.3. Analysis. Morphology of the product particles was examined using scanning electron microscopy (SEM, JEOL JSM6330F). Fourier transform infrared (FT-IR) spectra were collected on a Bruker FT-IR spectrometer by using the $\mathrm{KBr}$ pellet technique. ${ }^{1} \mathrm{H}$-NMR data were recorded on a JEOL JNM-GX 61D FT-NMR spectrometer operating at $400 \mathrm{MHz}$ in $\mathrm{CDCl}_{3}$, using TMS as internal standard.

\section{Results and Discussion}

3.1. Effect of $\mathrm{H}_{8} \mathrm{~L}$ Host Concentration. Experiments were performed using $\mathrm{H}_{8} \mathrm{~L}$ concentrations of $1 \times 10^{-3}-5 \times 10^{-4}$ $\mathrm{M}$ and a metal ion concentration of $5 \times 10^{-5} \mathrm{M}$; all other conditions were kept the same. We found that the extraction percentage increased with increasing $\mathrm{H}_{8} \mathrm{~L}$ concentration. The best extraction was achieved when $5 \times 10^{-4} \mathrm{M} \mathrm{H}_{8} \mathrm{~L}$ was used. As $\mathrm{H}_{8} \mathrm{~L}$ was soluble in nitrobenzene up to $4 \times 10^{-2} \mathrm{M}$ and up to $1 \times 10^{-2} \mathrm{M}$ in 1,2-dichloroethane at room temperature, the saturated solution was used as the stock solution.

3.2. Role of Extractant. Three organic solvents (nitrobenzene, dichloromethane, and chloroform) were also tested as inert diluents at a fixed $\mathrm{pH}$ for solutions containing an equal amount of metal ions and $\mathrm{H}_{8} \mathrm{~L}$. The phase volume ratio was maintained at 1:1 to avoid emulsion formation; this was found to be the most effective ratio. This means that the tendency for association is, in general, greater when the solvent-solute interactions are weaker; however, chloroform is the least effective. The exact cause of this type of behavior

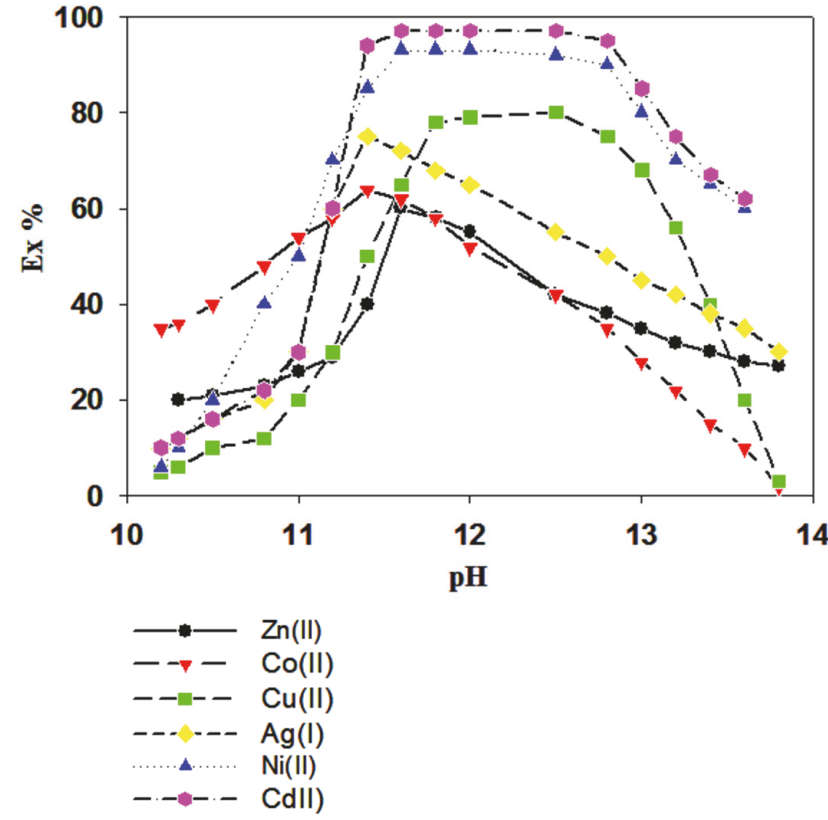

FIgURE 1: Extractability of all tested transition metal ions as a function of $\mathrm{pH}$. Organic phase: $H_{8} L=5 \times 10^{-4} \mathrm{M}$; aqueous phase: $=(\bullet) 5 \times 10^{-5} \mathrm{M}$; succinic acid $=0.01 \mathrm{M}$; and buffer solution: 0.01 $\mathrm{M}$; MES-NaOH (pH 5.0-7.0) and 0.1 M Tris- $\mathrm{HClO}_{4}$ (pH 7.0-9.0). $\left[\mathrm{Cd}^{2+}\right]=(\boldsymbol{\square}) 1 \times 10^{-4} \mathrm{M}, 0.2 \mathrm{M} \mathrm{NaClO}_{4} . \mathrm{O} / \mathrm{A}=1 ; \mathrm{T}=25^{\circ} \mathrm{C} . \mathrm{O}: \mathrm{A}$ represents the ratio between organic $(\mathrm{O})$ and aqueous $(\mathrm{A})$ volumes in the experiments.

is not known. It was observed that the extraction percentage increased with the diluent type in the order of chloroform > dichloromethane $>$ nitrobenzene.

3.3. Choice of Stripping Agent. After extraction of $\mathrm{Cd}^{2+}$ with $\mathrm{H}_{8} \mathrm{~L}$, the metal ions were stripped with $7 \mathrm{~mL}$ of various concentrations of mineral acid reagents, specifically $4 \mathrm{M} \mathrm{HCl}$, 0.1-5 $\mathrm{M} \mathrm{HNO}_{3}$, or $2 \mathrm{M} \mathrm{H}_{2} \mathrm{SO}_{4}$; lower concentrations of nitric acid $(<4.5 \mathrm{M})$ were not suitable as $\mathrm{Cd}^{2+}$ forms a stable complex. Finally, it was observed that $4 \mathrm{M} \mathrm{HCl}$ was suitable as a stripping agent.

3.4. Effect of Succinic Acid. Very small amounts of succinic was added to the reaction media to inhibit emulsification particularly in the case of $\mathrm{Cd}^{2+}, \mathrm{Cu}^{2+}$, and $\mathrm{Cr}^{3+}$ transition metal cations. By keeping all other parameters the same, experiments were performed using different concentrations of succinic acid. The best extraction was achieved when $0.01 \mathrm{M}$ succinic was used. It is noteworthy to mention that upon addition of the succinic acid into the highly basic buffer solution, the extraction percentage was stabilized probably due to the $\mathrm{pH}$ control.

3.5. Nature of the Extracted Species. At first, we studied the effect of $\mathrm{pH}$ on the extraction of several transition metal ions with $\mathrm{H}_{8} \mathrm{~L}$ in nitrobenzene. Specifically, the solvent extraction percentages of $\mathrm{Cd}^{2+}, \mathrm{Ni}^{2+}, \mathrm{Cu}^{2+}, \mathrm{Ag}^{+}, \mathrm{Co}^{2+}, \mathrm{Zn}^{2+}, \mathrm{Cr}^{3+}$, and $\mathrm{Mn}^{2+}$ transition metal cations were examined. Figure 1 

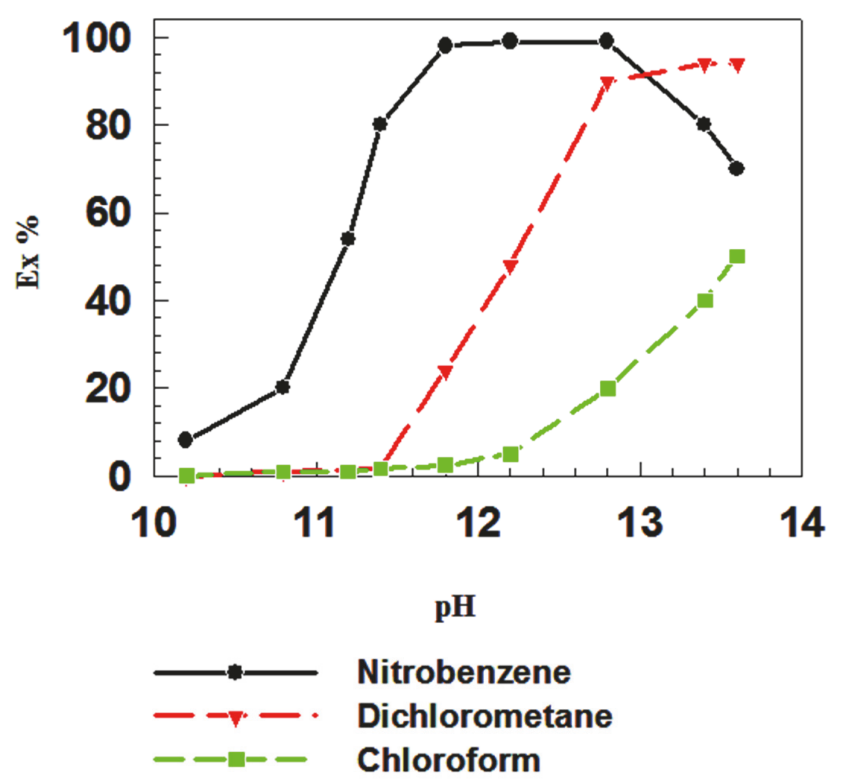

FIgURE 2: Effect of the organic solvent (nitrobenzene, dichloromethane, or chloroform) on the extraction percentage of $\mathrm{Cd}^{2+}$ with $\mathrm{H}_{8} \mathrm{~L} . \mathrm{H}_{8} L=5 \times 10^{-4} \mathrm{M}$; aqueous phase [metal ion]: = (๑) $5 \times 10^{-5} \mathrm{M}$. O/A = 1; succinic acid $=0.01 \mathrm{M}$; and buffer solution, $\mathrm{T}=25^{\circ} \mathrm{C}$.

shows that the percentage of metal ions extracted increases as the $\mathrm{pH}$ increases from 10.0 to 13.0. In the acidic or neutral $\mathrm{pH}$ region, metal ions were not extracted with $\mathrm{H}_{8} \mathrm{~L}$, whereas at $\mathrm{pH} 11.3$ more than $60 \%$ of metal ions were extracted with $\mathrm{H}_{8} \mathrm{~L}$. The maximum extraction percentage was observed in the $\mathrm{pH}$ range of the 11.5 to 13.00 for all tested samples. The extractability order is $\mathrm{Cd}^{2+}>\mathrm{Ni}^{2+}>$ $\mathrm{Cu}^{2+}>\mathrm{Ag}^{+}>\mathrm{Co}^{2+}>\mathrm{Zn}^{2+} . \mathrm{H}_{8} \mathrm{~L}$ has phenolic hydroxyl groups which deprotonate at $\mathrm{pH}>\mathrm{ca} .10$ and deprotonated $\mathrm{H}_{8} \mathrm{~L}$ can extract the metal ions. Among the cations tested, almost the same percentages of $\mathrm{Cd}^{2+}$ and $\mathrm{Ni}^{2+}$ ions were extracted under the experimental conditions. By contrast, no amounts of $\mathrm{Cr}^{3+}$ and $\mathrm{Mn}^{2+}$ were extracted, possibly due to the formation of a precipitate with ammonia solution. The results indicate that $\mathrm{H}_{8} \mathrm{~L}$ has a good affinity for complexation with transition metal ions. The study of $\mathrm{pH}$ effect indicates that the extraction mechanism depends on a proton exchange mechanism together with hydrogen bonding. Petit et al. also reported a dinuclear cobalt(II) complex of calix[8]arenes compound, prepared by solvothermal reaction of cobalt(II) acetate with $p$ - $t$-butylcalix[8] arene and trimethylamine; the compound was formed by hydrogen bond bridging [33].

The effects of three organic solvents, nitrobenzene, dichloromethane, and chloroform, were examined for both $\mathrm{Cd}^{2+}$ (Figure 2) and $\mathrm{Ni}^{2+}$ (Figure 3) in the $\mathrm{pH}$ range of 1013.5. Nitrobenzene was very effective as an extractant for both $\mathrm{Cd}^{2+}$ and $\mathrm{Ni}^{2+}$ metal ions, extracting $96 \%$ of these metal ions in the $\mathrm{pH}$ range of 11.50-12.70. Dichloromethane was effective in the $\mathrm{pH}$ range $11.4-13$ for $\mathrm{Cd}^{2+}$, whereas the effective $\mathrm{pH}$ range for $\mathrm{Ni}^{2+}$ was 12-13. Chloroform was less effective as an extractant at all $\mathrm{pH}$ values tested, showing

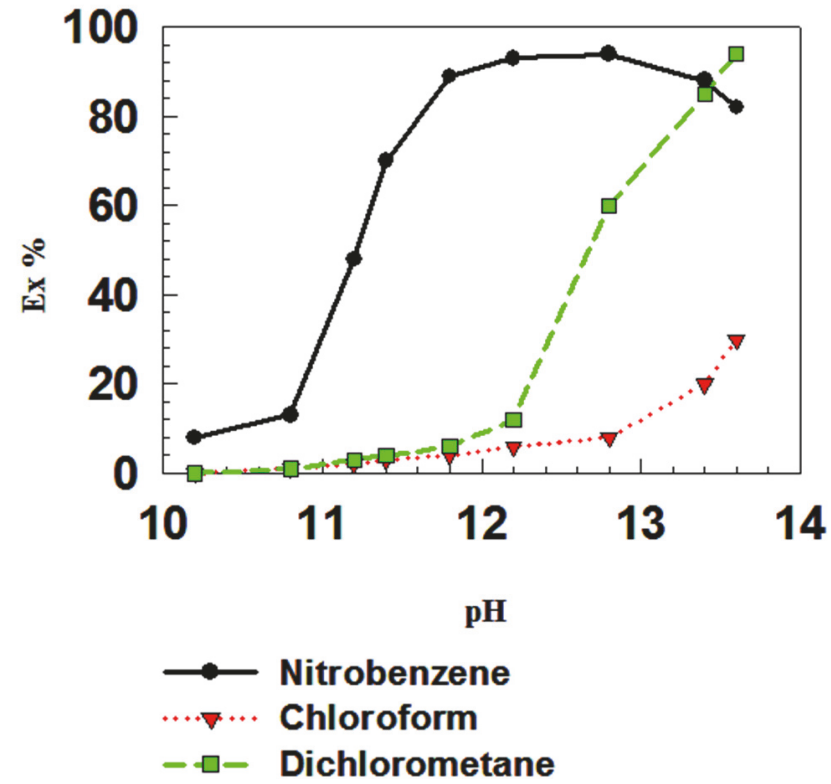

Figure 3: Effect of the organic solvent (nitrobenzene, dichloromethane, or chloroform) on the extraction percentage of $\mathrm{Ni}^{2+}$ with $\mathrm{H}_{8} \mathrm{~L}$. $p$-calix[8] $=5 \times 10^{-4} \mathrm{M}$; aqueous phase [metal ion]: $=(\bullet) 5 \times 10^{-5} \mathrm{M}$. succinic acid $=0.01 \mathrm{M}$ and buffer solution, $\mathrm{O} / \mathrm{A}=1 ; \mathrm{T}=25^{\circ} \mathrm{C}$.

only $50 \%$ extraction of $\mathrm{Cd}^{2+}$ and $\mathrm{Ni}^{2+}$ combined and similar extraction percentages for $\mathrm{Cd}^{2+}$ and $\mathrm{Ni}^{2+}$ individually. It has been reported that the $\mathrm{H}_{6} \mathrm{~L}$ complex could be obtained as an adduct with chloroform $(1 \mathrm{M})$; however, chloroform could not be removed from the adduct after calcination at $130^{\circ} \mathrm{C}$ for 3 days under reduced pressure. This indicates that the chloroform molecule might be encapsulated within the cavity of the calixarene and particularly for p-t-butyl calix $[6]$ arene $\left[\mathrm{H}_{6} \mathrm{~L}\right]$ molecule, which may account for the low extraction percentage obtained in the chloroform solution [25]. Three types of organic solvents were tested and the nitrobenzene is found to be the most efficient. Two other solvents, dichloromethane and chloroform, are least effective. The exact cause of this type of behavior is not known. Masuda et al. observed that the relative descending order of extraction with other solvents is not the same with $\mathrm{H}_{6} \mathrm{~L}$ and the same order does not necessarily accord the order of their dielectric constants [31]. Actually the extraction percentages of $\mathrm{Ce}(\mathrm{III})$ with $\mathrm{H}_{6} \mathrm{~L}$ were $95 \%, 27 \%$, and $18 \%$ at $\mathrm{pH} 11.85$ in the case of organic solvents nitrobenzene, dichloromethane, and chloroform. The dielectric contestants of nitrobenzene, dichloromethane, and chloroform are 34.82, 7.77, and 4.80, respectively. Therefore, it can be assumed that the dielectric contestant of the medium has some contribution in the extraction process. However, the main factor determining the extraction efficiency in the extraction process must be taken into account and a better term correlating the relative extraction order is solubility parameter. Moreover, Thuéry et al. reported that the reaction at room temperature between $\mathrm{H}_{8} \mathrm{~L}$ and an excess of trimethylamine in chloroform provided a solid that could be recrystallized in methanol 


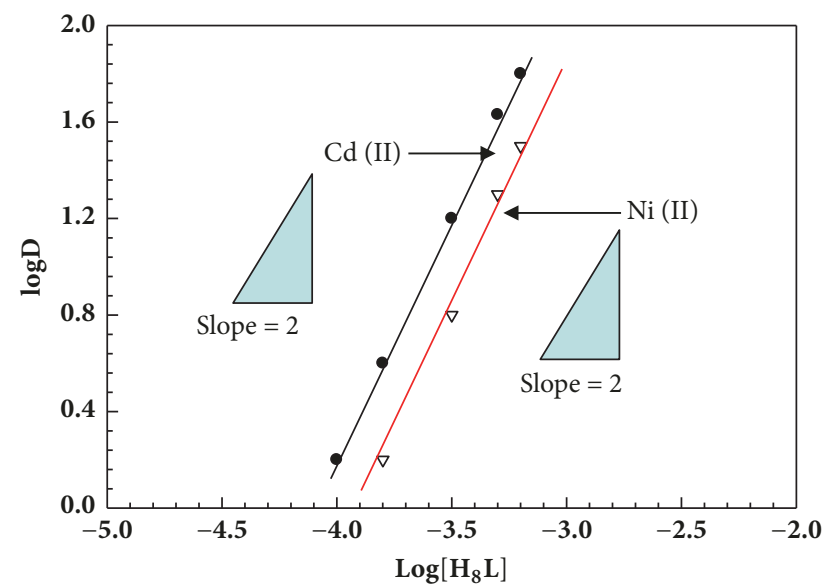

Figure 4: Plot of $\log \mathrm{D}$ vs. $\log \left[\mathrm{H}_{\mathrm{n}} \mathrm{L}\right]$ for $\mathrm{Cd}^{2+}$ and $\mathrm{Ni}^{3+}$ under the same reaction condition of Figure 3.

to yield dark red crystals of new compound suitable for $\mathrm{X}$-ray crystallography. Therefore, we can conclude that the chloroform solvents have some affinity and/or suitable for complex formation with $\mathrm{H}_{8} \mathrm{~L}$ ligand [34].

3.6. Slope Analysis. A traditional and effective means of obtaining both stoichiometric and equilibrium constant information about extraction processes, slope analysis, are based on an examination of the logarithmic variation of the distribution ratio, $\mathrm{D}$, with relevant experimental variables. The log-log plots of the extraction in the form of $\mathrm{D}$ vs. a concentration variable indicate the stoichiometry of the formation of the extractable complex and thus lead to the derivation of a suitable equilibrium expression and then to the calculation of equilibrium constants.

Since the extraction reagents exhibited high selectivity for $\mathrm{Cd}^{2+}$ and $\mathrm{Ni}^{2+}$, detailed extraction behavior for $\mathrm{Cd}^{2+}$ and $\mathrm{Ni}^{2+}$ was investigated by slope analysis, the continuous variation method, and by loading tests. The extraction mechanism was studied by evaluating the composition of the extracted $\mathrm{Cd}^{2+}$ and $\mathrm{Ni}^{2+}$ species. Figure 4 shows the effect of the initial concentration of $\mathrm{H}_{8} \mathrm{~L}$ in the organic phase on the extraction of $\mathrm{Cd}^{2+}$ and $\mathrm{Ni}^{2+}$ from an aqueous ammonia solution. With increasing initial concentration of $\mathrm{H}_{8} \mathrm{~L}$, straight lines with a slope of 2 were obtained in the $\log \mathrm{D}$ vs. $\log \left[\mathrm{H}_{8} \mathrm{~L}\right]$ plots for $\mathrm{Cd}^{2+}$ and $\mathrm{Ni}^{2+}$, indicating that the binding ratio of $\mathrm{H}_{8} \mathrm{~L}$ with $\mathrm{Cd}^{2+}$ and $\mathrm{Ni}^{2+}$ is 2:1. Figure 5 shows the effect of the initial concentration of ammonia in the aqueous phase on the extraction of $\mathrm{Cd}^{2+}$ and $\mathrm{Ni}^{2+}$. The $\log \mathrm{D}$ value increases linearly with an increasing initial concentration of ammonia with a slope of 2 . These findings suggest that a 2:1 $\left(\mathrm{H}_{8} \mathrm{~L}\right.$ : metal $)$ complex was extracted into the organic phase by releasing an equimolar amount of protons from $\mathrm{H}_{8} \mathrm{~L}$ along with two ammonia molecules.

Distribution experiments were carried out in order to obtain information on the viability of the extraction process, the stoichiometry and distribution equilibrium of the extracted metal ions between phases, and the extent of $\mathrm{Cd}^{2+}$ and $\mathrm{Ni}^{2+}$ extraction. During this experiment, the

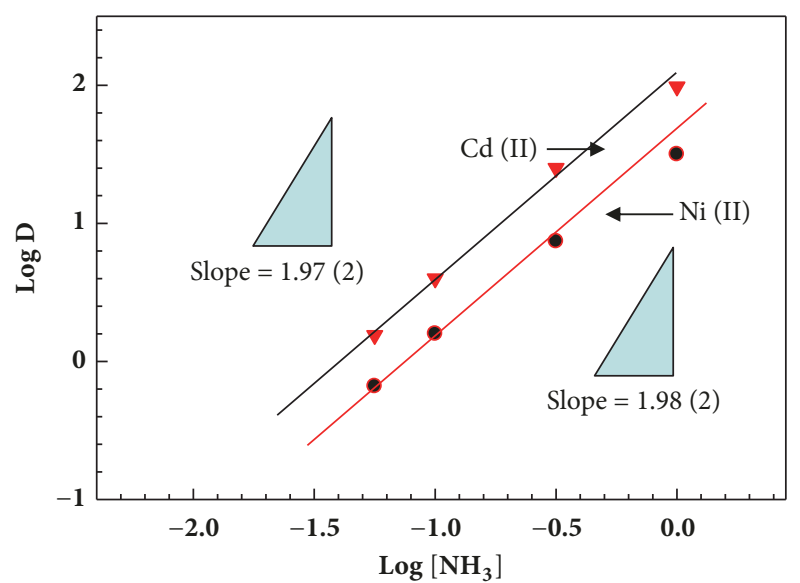

Figure 5: Plot of $\log \mathrm{D}$ vs. $\log \left[\mathrm{NH}_{3}\right]$ for $\mathrm{Cd}^{2+}$ and $\mathrm{Ni}^{3+}$ with $\mathrm{H}_{8} \mathrm{~L}$ under the same reaction condition of Figure 3.

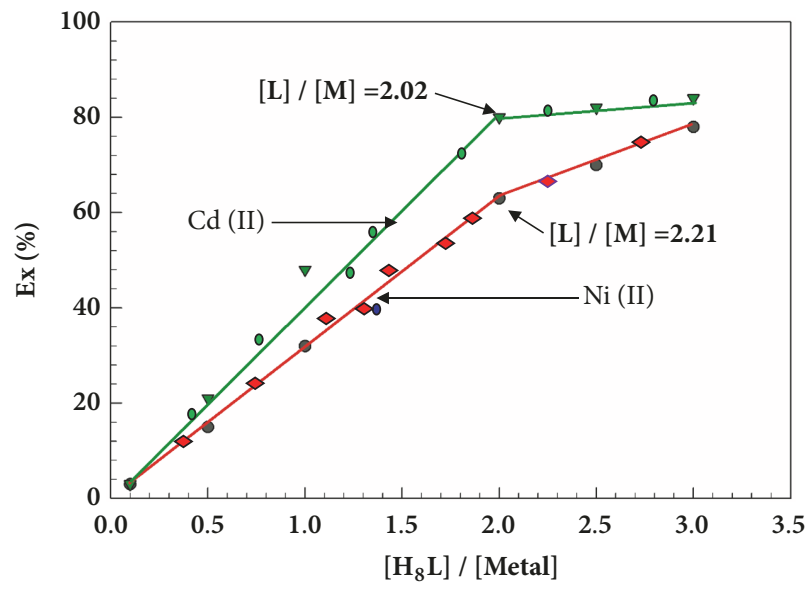

FIGURE 6: Plots of percentage extraction vs. molar ratio [L]/[M] for the extraction of $\mathrm{Cd}^{2+}$ and $\mathrm{Ni}^{3+}$ with $\mathrm{H}_{8} \mathrm{~L}$ under the same reaction condition of Figure 3. O:A = 1:1. Symbol (empty green inverted triangle), (filled green circle) (repeated) (filled red diamond) (filled red circle) (repeated) $-\mathrm{H}_{8} \mathrm{~L} ; \mathrm{O} / \mathrm{A}=1 ; \mathrm{T}=25^{\circ} \mathrm{C}$.

concentrations of $\mathrm{Cd}^{2+}$ and $\mathrm{Ni}^{2+}$ were kept constant at 1 $\times 10^{-3} \mathrm{M}$, while the concentration of the extractant was varied from $1 \times 10^{-4}$ to $2 \times 10^{-3} \mathrm{M}$. This means that the relative concentration of the extractant $\mathrm{H}_{8} \mathrm{~L}$ (defined as the molar ratio of the initial extractant concentration and the concentration of the extracted metal) changed from 0.1 to 3.4 (Figure 6). A plot of the residual concentration of $\mathrm{Cd}^{2+}$ and $\mathrm{Ni}^{2+}$ in the aqueous phase, against the relative concentration of extractant, is presented in Figure 6. Initially, experiments were completed three times to examine their reproducibility. These results are also presented in Figure 6. As can be seen, the extraction method showed good reproducibility. An extraction percentage higher than $75 \%$ was obtained using $\mathrm{H}_{8} \mathrm{~L}$ at low concentrations of $\mathrm{Cd}^{2+}$ and $\mathrm{Ni}^{2+}$. For $\mathrm{Cd}^{2+}$ and $\mathrm{Ni}^{2+}$ extracted by the same reaction condition, the higher Ex $\%$ of $\mathrm{Cd}^{2+}$ must have a high extraction equilibrium constant. That is why the slope of straight line after the inflection point 
in Figure 6 becomes more horizontal in green line $\left(\mathrm{Cd}^{2+}\right)$ than red line $\left(\mathrm{Ni}^{2+}\right)$.

As mentioned above the molar ratio of $\mathrm{H}_{8} \mathrm{~L}$ : metal was 2:1. These extraction studies suggest that the 2:1 $\left(\mathrm{H}_{8} \mathrm{~L}\right.$ : metal) complex was extracted into the organic phase releasing 1 $M$ protons from $1 \mathrm{M} \mathrm{H}_{8} \mathrm{~L}$, accompanying two ammonia molecules [Figures 4 and 5]. The extraction equilibrium and the extraction equilibrium constant $\mathrm{K}_{\mathrm{ex}}$ can be expressed as

$$
\begin{aligned}
& \mathrm{M}\left(\mathrm{NH}_{3}\right)_{\mathrm{i}}^{2+}+2 \mathrm{H}_{8} \mathrm{~L}_{(\mathrm{o})}+2 \mathrm{NH}_{3} \\
& =\mathrm{M}\left(\mathrm{NH}_{3}\right)_{\mathrm{i}+2} \mathrm{H}_{6} \mathrm{~L}_{(\mathrm{o})}+2 \mathrm{H}^{+} \\
& \mathrm{K}_{\mathrm{ex}}=\frac{\left[\mathrm{M}\left(\mathrm{NH}_{3}\right)_{\mathrm{i}+2} \mathrm{H}_{6} \mathrm{~L}\right]_{\mathrm{o}}\left[\mathrm{H}^{+}\right]^{2+}}{\left[\mathrm{M}\left(\mathrm{NH}_{3}\right)_{\mathrm{i}}^{2+}\right]\left[\mathrm{H}_{8} \mathrm{~L}\right]_{\mathrm{o}}^{2}\left[\mathrm{NH}_{3}\right]^{2}}
\end{aligned}
$$

where (o) indicates the species in the organic phase. Equation (3) can be simplified as follows using the distribution ratio of the metal $\left(\mathrm{D}=\left[\mathrm{M}\left(\mathrm{NH}_{3}\right)_{\mathrm{i}+2} \mathrm{H}_{8} \mathrm{~L}\right]_{\mathrm{o}} /\left[\mathrm{M}\left(\mathrm{NH}_{3}\right)_{\mathrm{i}}{ }^{2+}\right]\right)$ :

$$
\begin{aligned}
\mathrm{K}_{\mathrm{ex}}^{\prime} & =\frac{\mathrm{D}[\mathrm{H}]^{2}}{\left[\mathrm{H}_{6} \mathrm{~L}\right]_{\mathrm{o}}^{2}\left[\mathrm{NH}_{3}\right]^{2}} \\
\log \mathrm{D} & =\log \mathrm{K}_{\mathrm{ex}}^{\prime}+2 \log \left[\mathrm{H}_{8} \mathrm{~L}\right]_{\mathrm{o}}+2 \mathrm{pH}+2 \log \left[\mathrm{NH}_{3}\right]
\end{aligned}
$$

From the above observations, it is suggested that the ammonia molecules and amine complex participate in the extraction of transition metal ions with $\mathrm{H}_{8} \mathrm{~L}$.

The extraction of transition metal ions with $\mathrm{H}_{8} \mathrm{~L}$ from the aqueous phase, containing $0.1 \mathrm{M}$ ethylenediamine $\left[\mathrm{C}_{2} \mathrm{H}_{4}\left(\mathrm{NH}_{2}\right)_{2}\right]$ and $0.1 \mathrm{M}$ trimethylenediamine $\left[\left(\mathrm{CH}_{2}\right)_{3}\left(\mathrm{NH}_{2}\right)_{2}\right]$ instead of ammonia, into the dichloromethane solution was also examined. It is worth noting that extraction of $\mathrm{Co}^{2+}$ and $\mathrm{Ni}^{2+}$ from the aqueous phase containing ethylene diamine was suppressed $(\mathrm{Ex} \%=0)$. On the other hand, $\mathrm{Cu}^{2+}$ and $\mathrm{Cd}^{2+}$ were extracted remarkably well $\left(\mathrm{Cu}^{2+}=100 \%\right.$ and $\left.\mathrm{Cd}^{2+}=90 \%\right)$ from the aqueous phase containing ethylene diamine. The interaction of calixarenes and amines in the dichloromethane solution likely involves the following two-step process: (i) proton transfers from the calixarene to the amine to form the amine cation and then (ii) the calixarene anion forms an endo-calix complex by association with the amine cation [35]. However, we think these reactions simultaneously take place and reach equilibrium at certain conditions.

To understand complexation in the aqueous phase, the distribution ratio of the $\mathrm{M}(\mathrm{en})_{2}$ and $\mathrm{M}(\mathrm{en})_{3}\left[(\mathrm{en})_{2}=\right.$ ethylene diamine and $(\mathrm{en})_{3}=$ trimethylene diamine] species in the aqueous phase about each metal ion before extraction, using the formation constant with ethylene di and triamine, was calculated. Table 1 shows the distribution ratios of the $\mathrm{M}(\mathrm{en})_{2}$ and $\mathrm{M}(\mathrm{en})_{3}$ species in the aqueous phase before extraction and the extraction percentage for extraction with $\mathrm{H}_{8} \mathrm{~L}$ into dichloromethane. The distribution ratios for the complexations with $\mathrm{H}_{8} \mathrm{~L}$ are comparable and indicative of high efficiency (Table 1). The values of the distribution ratios of $\mathrm{M}(\mathrm{en})_{2}$ and $\mathrm{M}(\mathrm{en})_{3}$ species in the aqueous phase before extraction are integers. As mentioned above, the extraction
TABLE 1: Extraction percentage (Ex\%) of the transition metal ions with $\mathrm{H}_{8} \mathrm{~L}$ from ethylene diamine into dichloromethane at $25^{\circ} \mathrm{C}$ and distribution ratio of $\mathrm{M}(\mathrm{en})_{2}$ and $\mathrm{M}(\mathrm{en})_{3}$ in the aqueous phase before extraction. Uncertainties are given in parentheses as standard errors of the mean $(\mathrm{N}=3)$.

\begin{tabular}{lccc}
\hline & $\% \mathrm{E}$ & $\begin{array}{c}\mathrm{M}(\mathrm{en})_{2}{ }^{*} \\
(\%)\end{array}$ & $\begin{array}{c}\mathrm{M}(\mathrm{en})_{3}{ }^{* *} \\
(\%)\end{array}$ \\
\hline $\mathrm{Co}(\mathrm{II})$ & 0 & 0 & 100 \\
$\mathrm{Ni}(\mathrm{II})$ & 0 & 0 & 100 \\
$\mathrm{Cu}(\mathrm{II})$ & $97.0(2)$ & 100 & 40 \\
$\mathrm{Zn}(\mathrm{II})$ & $46.0(3)$ & 3 & 97 \\
$\mathrm{Ag}(\mathrm{I})$ & $52.7(5)$ & 99 & 35 \\
$\mathrm{Cd}(\mathrm{II})$ & $90.1(1)$ & 15 & 85 \\
\hline
\end{tabular}

$*(\mathbf{e n})_{2}=$ ethylene diamine, $* *(\mathbf{e n})_{3}=$ ethylene triamine.

of $\mathrm{Co}^{2+}$ and $\mathrm{Ni}^{2+}$ metal ions was suppressed. Thus, most of the existing species in the aqueous phase are $\mathrm{M}(\mathrm{en})_{3}$, while few $\mathrm{M}(\mathrm{en})_{2}$ species were present, whereas in the case of $\mathrm{Cu}^{2+}$ most of the extracted species present in the aqueous phase were $\mathrm{M}(\mathrm{en})_{2}$ species. These data suggest that the existence of $\mathrm{M}(\mathrm{en})_{2}$ species diverts and/or controls the extraction with $\mathrm{H}_{8} \mathrm{~L}$ from the aqueous phase containing ethylene diamine to some extent. This can be explained by steric factors influencing the binding of the ligands to the metal ions. It means that probably the small molecule are encapsulated by larger molecular and steric barriers keep the guest from escaping the host. From the above results, masking effects of metal ions with amines were also observed, particularly metal ions showing high affinity with amines.

We additionally studied the composition of the $\mathrm{Cu}^{2+}$ and $\mathrm{Cd}^{2+}$ extracted species according to the molar ratio method. A plot of $\log \mathrm{D}$ vs. $\log \left[\mathrm{H}_{8} \mathrm{~L}\right]$ was constructed and a straight line was found with a slope of 1 , indicating a molar ratio of $\mathrm{H}_{8} \mathrm{~L}:$ metal $=1: 1$, which is different from the composition of species in the case of the ammonia aqueous phase. The effect of $\mathrm{pH}$ on the extraction of $\mathrm{Cu}^{2+}$ was also verified. As $\log \mathrm{D}$ increases linearly with an increase in $\mathrm{pH}$, where a slope of 2 was obtained.

Thus, the extraction equilibrium can be expressed as (en= $\left.\mathrm{H}_{2} \mathrm{~N}\left(\mathrm{CH}_{2}\right)_{2} \mathrm{NH}_{2}\right)$

$$
\mathrm{M}_{(\mathrm{en}) 2}^{2+}+\mathrm{H}_{8} \mathrm{~L}_{(\mathrm{O})}=\mathrm{M}_{(\mathrm{en}) 2} \mathrm{H}_{6} \mathrm{~L}_{(\mathrm{O})}+2 \mathrm{H}^{+}
$$

Table 2 shows the elemental analysis data of the $\mathrm{Cu}^{2+}$. $\mathrm{H}_{8} \mathrm{~L}$ and $\mathrm{Cd}^{2+}-\mathrm{H}_{8} \mathrm{~L}$ complexes. These data indicate that the extracted species from the aqueous phase containing ethylene diamine was $\mathrm{M}(\mathrm{en})_{2}$ not $\mathrm{M}(\mathrm{en})_{3}$, in agreement with our initial assumption based on Table 1 .

It has been reported that, in the extraction of metal ions using calix[n]arenes, the metal ion selectivity is related to the ring size of the calix [n] arene and to the radii of the metal ions $[9,10]$. The present extraction study using $\mathrm{H}_{8} \mathrm{~L}$ accompanied by amines indicated that size is key to the selectivity, as the diameter of the $\mathrm{H}_{8} \mathrm{~L}$ ring (4-4.4 $\AA$ ) is sufficient to fit the $\mathrm{M}(\mathrm{en})_{2}$ complex (where the distance between the both ends of amino proton is ca. $4.0 \AA$ ). A possible structure of $\mathrm{Cu}^{2+}$ $\mathrm{H}_{8} \mathrm{~L}$ is given in Scheme 1. An X-ray results is essential to 
TABLE 2: Elemental analysis of $\mathrm{Cu}^{2+}-\mathrm{H}_{8} \mathrm{~L}$ and $\mathrm{Cd}^{2+}-\mathrm{H}_{8} \mathrm{~L}$ complexes and estimated chemical formula.

\begin{tabular}{|c|c|c|c|c|c|c|c|}
\hline \multicolumn{4}{|c|}{$\mathrm{Cu}^{2+}:$ estimate chemical formula } & \multicolumn{4}{|c|}{$\mathrm{Cd}^{2+}:$ estimate chemical formula } \\
\hline \multicolumn{4}{|c|}{$\mathrm{Cu}(\mathrm{en})_{2} \mathrm{H}_{6} \mathrm{~L} .5 \mathrm{H}_{2} \mathrm{O}$} & \multicolumn{4}{|c|}{$\mathrm{Cd}(\mathrm{en})_{2} \mathrm{H}_{6} \mathrm{~L} \cdot 3 \mathrm{H}_{2} \mathrm{O}$} \\
\hline \multicolumn{4}{|c|}{$\mathrm{H}(\%) \mathrm{C}(\%) \mathrm{N}(\%)$} & \multicolumn{4}{|c|}{$\mathrm{H}(\%) \mathrm{C}(\%) \mathrm{N}(\%)$} \\
\hline Obs. & 8.37 & 70.89 & 3.56 & Obs. & 8.18 & 69.90 & 3.49 \\
\hline Calc. & 8.73 & 70.40 & 3.57 & Calc. & 8.41 & 69.83 & 3.54 \\
\hline
\end{tabular}

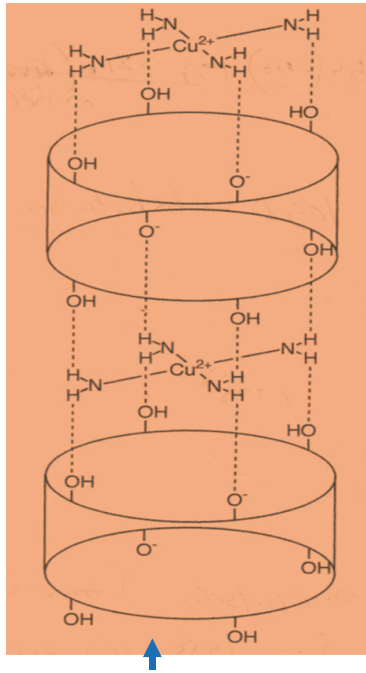

(a) $\left[\mathrm{Cu}\left(\mathrm{en}_{2}\right] \mathrm{n}-\left(\mathrm{H}_{8} \mathrm{~L}\right) \mathrm{n}\right.$

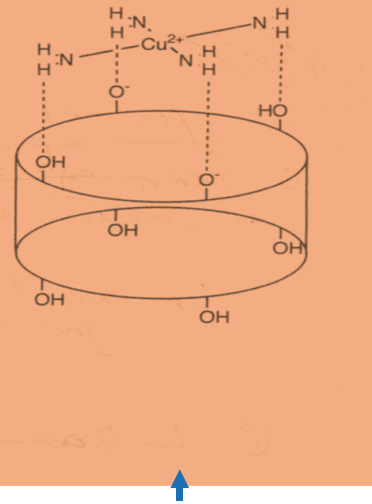

(b) $\mathrm{Cu}(\text { en })_{2}-\mathrm{H}_{8} \mathrm{~L}$
Scheme 1: Structure of $\mathrm{Cu}(\mathrm{en})_{2}-\mathrm{H}_{8} \mathrm{~L}$ complex.

determine a compound structure. At present, our research is now progressing in this direction.

As mentioned above $\mathrm{Cd}^{2+}$ is very toxic and inhaling cadmium dust leads to kidney problems which can be fatal. Therefore, complexation studies of $\mathrm{Cd}^{2+}-\mathrm{H}_{8} \mathrm{~L}$ complexes were also performed using FESEM, FTIR, and ${ }^{1} \mathrm{H}$ NMR spectroscopy for more information of $\mathrm{Cd}^{2+}$ extraction with $\mathrm{H}_{8} \mathrm{~L}$. FESEM images of $\mathrm{H}_{8} \mathrm{~L}$ and $\mathrm{Cd}^{2+}-\mathrm{H} 8 \mathrm{~L}$ showed very unique surface morphology. The $\mathrm{H}_{8} \mathrm{~L}$ had rod-like particles with almost $10 \mu \mathrm{m}$ long and less than $1 \mu \mathrm{m}$ wide [Figure 7(a)]. However, the $\mathrm{Cd}^{2+}-\mathrm{H}_{8} \mathrm{~L}$ morphology was totally changed in compare with $\mathrm{H}_{8} \mathrm{~L}$ alone. The $\mathrm{Cd}^{2+}-\mathrm{H}_{8} \mathrm{~L}$ sample had two types of particle sizes as shown in Figures $7(\mathrm{a})$ and $7(\mathrm{~b})$, respectively. The nanosize spherical particles were $\mathrm{Cd}^{2+}$ ions and the square or bigger size particles were $\mathrm{H}_{8} \mathrm{~L}$ as evidence by EDX analysis. The EDX and elemental analysis showed almost the same results. It is interesting that the $\mathrm{Cd}^{2+}$ ions were homogeneously dispersed and/or distributed over the $\mathrm{H}_{8} \mathrm{~L}$ ligand. Figure 8(a) shows the EDX spectrum of big particles marked by red arrow in Figure 7(b). The atomic percentage of $C$ was 69.26 for the big size particles. Very little amount of $\mathrm{Cd}^{2+}$ was also obtained during EDX analysis of big size particles. On the other hand, the spherical particles had mostly $\mathrm{Cd}^{2+}$ ion and atomic percentage of $\mathrm{Cd}$ was 33.78 [Figure 8(b), the EDX spectrum of spherical particle was based on Figure 7(c), marked by red arrow]. Almost the same results were obtained for different location based on particles size. The EDX results shown in Figures $8(\mathrm{a})$ and $8(\mathrm{~b})$ indicate the presence of $\mathrm{Cd}, \mathrm{C}, \mathrm{Au}, \mathrm{Cu}$, and $\mathrm{O}$. The $\mathrm{Au}$ and $\mathrm{Cu}$ were found due to gold coating over the sample and $\mathrm{Cu}$ substrate was used.

The FTIR spectrum of $\mathrm{H}_{8} \mathrm{~L}$ and $\mathrm{Cd}^{2+}-\mathrm{H}_{8} \mathrm{~L}$ is shown in Figures 9(a) and 9(b), respectively. In the FTIR spectra of the complexes, the intensities or wave numbers of the stretching vibration of the $\mathrm{OH}$ groups change drastically with complexation by breakage of the especially strong intramolecular hydrogen bonding existing in the free ligands [30]. The IR absorption bands at $3187 \mathrm{~cm}^{-1}$ due to $v \mathrm{~N}-\mathrm{H}$ : free ethylene diamine [36] shifted to $3361 \mathrm{~cm}^{-1}$ upon extraction of $\mathrm{Cd}^{2+}$ with $\mathrm{H}_{8} \mathrm{~L}$. This indicates that hydrogen bonding was likely present in the $\mathrm{M}(\mathrm{en})_{2}-\mathrm{H}_{8} \mathrm{~L}$ complex. The associated natures of $\mathrm{C}\left(\mathrm{CH}_{3}\right)_{3},-\mathrm{CH}_{2}-$, and hydroxyl group have been reported previously [30]. The band $\mathrm{C}\left(\mathrm{CH}_{3}\right)_{3}$ gives a sharp absorption band at ca. $2944 \mathrm{~cm}^{-1}$, and this peak intensity was weakened after making a complex with $\mathrm{Cd}^{2+}$ cation. The $\nu(\mathrm{C}=\mathrm{C})$ vibration bands shift by about $30 \mathrm{~cm}^{-1}$ (i.e., from 1605 to $1638 \mathrm{~cm}^{-1}$ ) toward higher frequencies. It has been also recorded that the $-\mathrm{CH}_{2}-$ vibrations almost disappeared and the very strong peak at $1489 \mathrm{~cm}^{-1}$ was disappeared. The differences in the infrared spectra may be caused by hydrogen bonding. As a whole, all the peaks of $\mathrm{Cd}^{2+}-\mathrm{H}_{8} \mathrm{~L}$ composites were shifted to higher energy direction, indicating the strong interaction between $\mathrm{Cd}^{2+}$ and $\mathrm{H}_{8} \mathrm{~L}$.

The solution behavior of the complexes was determined by ${ }^{1} \mathrm{H}$-NMR spectroscopy in $\mathrm{CDCl}_{3}$ at room temperature. In the spectra of $\mathrm{H}_{8} \mathrm{~L}$ [Figure $10(\mathrm{a})$ ], and $\mathrm{Cd}^{2+}-\mathrm{H}_{8} \mathrm{~L}$ [Figure 10(b)], each spectrum shows one singlet resonance for protons of $-\mathrm{C}\left(\mathrm{CH}_{3}\right)_{3}$ at $\delta=1.25$. For $\mathrm{H}_{8} \mathrm{~L}$, singlet resonances of $\mathrm{Ar}-\mathrm{H}$ are observed at $\delta=7.12$ and $7.14 \mathrm{ppm}$, respectively; for Ar- $\mathrm{OH}$ these resonances are at $\delta=9.63$, respectively. A new signal appeared at chemical shift of $\delta=2.62$ which was not observed in the $\mathrm{H}_{8} \mathrm{~L}$. In our previous study, we also observed one singlet at around $\delta 3.00$ for $\mathrm{Ce}^{3+}-\mathrm{H}_{8} \mathrm{~L}$ and $\mathrm{Ce}^{3+}-\mathrm{H}_{6} \mathrm{~L}$ probably for the bridging methane groups due to the different environments of the hydrogen atoms on the methylene group [30]. In the ${ }^{1} \mathrm{H}$ NMR spectra, peaks at 3.5 and 4.4 ppm were observed (due to the nonequivalent methylene protons (Ar$\mathrm{CH}_{\mathrm{A}} \mathrm{H}_{\mathrm{B}}-\mathrm{Ar}$ ) in the free $\mathrm{H}_{8} \mathrm{~L}$ which converge to $3.8 \mathrm{ppm}$ in the $\mathrm{Cd}(\mathrm{en})_{2}-\mathrm{H}_{8} \mathrm{~L}$ complex after extraction. This indicates that the cone conformation of $\mathrm{H}_{8} \mathrm{~L}$ converts into the 1,3,5,7-alternate conformation.

In this study, the $\mathrm{H}_{8} \mathrm{~L}$-ester compounds were also synthesized according to published procedures [37]. The extraction percentage of any metal ion was poor throughout the entire 


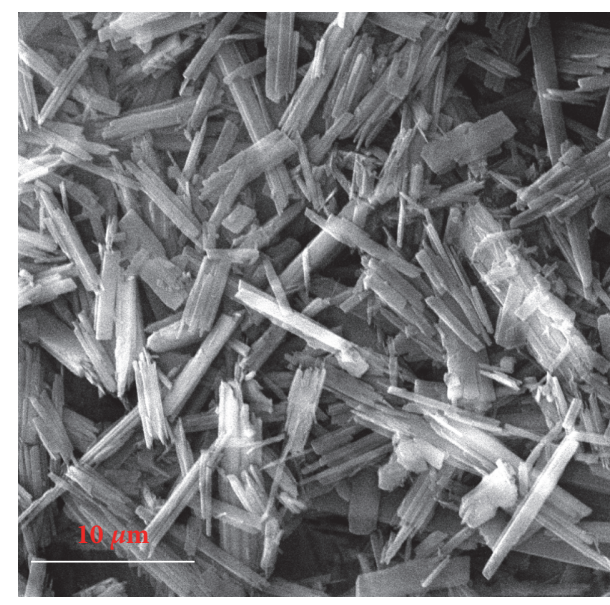

(a)

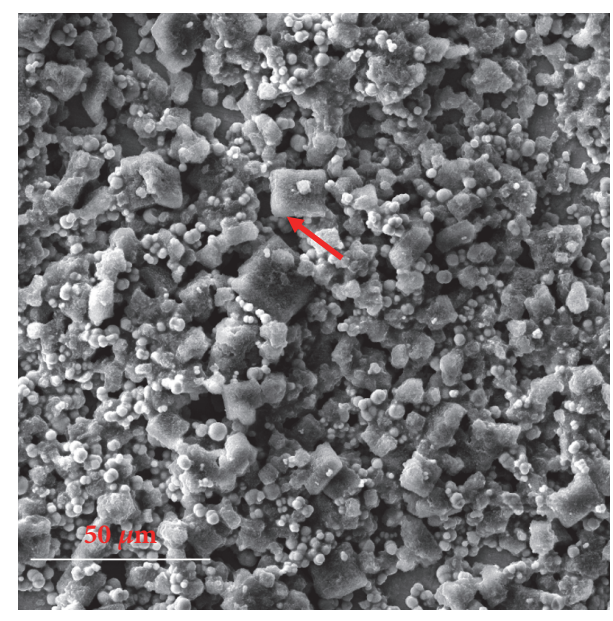

(b)

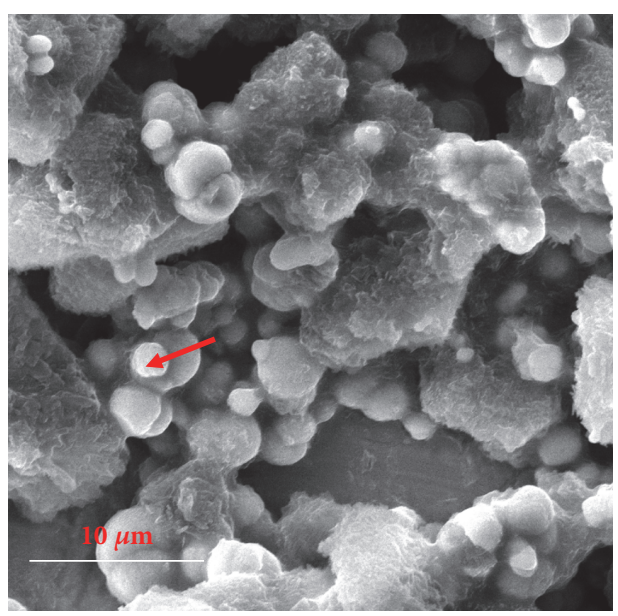

(c)

FIgURE 7: FESEM images of the samples: (a) $\mathrm{H}_{8} \mathrm{~L}$, (b) $\mathrm{Cd}^{2+}-\mathrm{H}_{8} \mathrm{~L}$, and (c) sample (b) at high magnification.

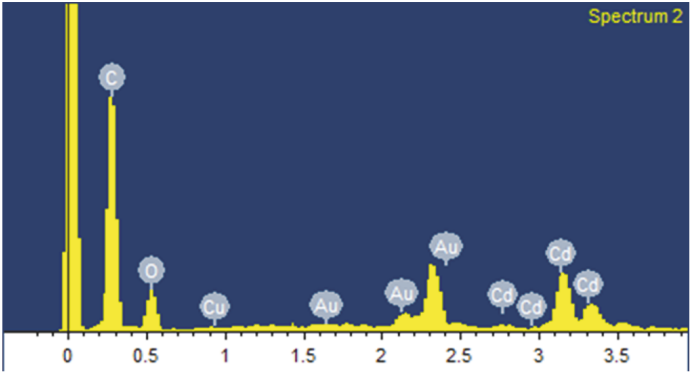

(a)

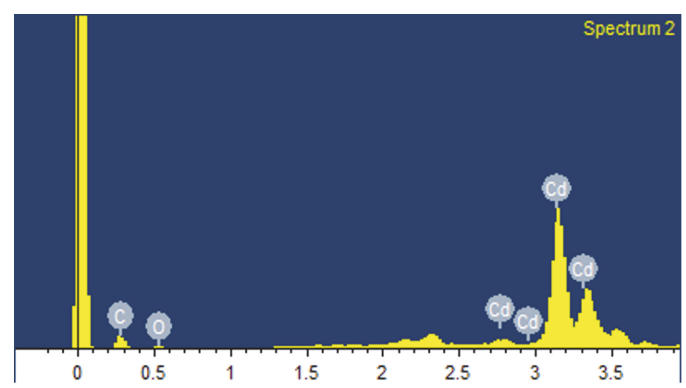

(b)

Figure 8: EDX spectra of (a) $\mathrm{H}_{8} \mathrm{~L}$ and (b) $\mathrm{Cd}^{2+}-\mathrm{H}_{8} \mathrm{~L}$. EDX spectra for the region marked by an arrow in (b), and (c) of $\mathrm{Cd}^{2+}-\mathrm{H}_{8} \mathrm{~L}$ in Figure 7 .

range of $\mathrm{pH}$ used. In fact, the liquid-liquid extraction ability of transition metal ions with the $\mathrm{H}_{8} \mathrm{~L}$-ester $/ \mathrm{CH}_{2} \mathrm{COOC}_{2} \mathrm{H}_{5}$ derivative was low in comparison with $\mathrm{H}_{8} \mathrm{~L}$ alone. It is thought that the $\mathrm{H}_{8} \mathrm{~L}$ becomes an anion due to deprotonation.
The $\mathrm{H}_{8} \mathrm{~L}$-ester, which is modified from calix[8] arene, is more flexible than both the calix[4] arene and calix[6] arene derivatives; however, it did not show a good extraction capability for $\mathrm{Co}^{2+}, \mathrm{Ni}^{2+}, \mathrm{Zn}^{2+}$, and $\mathrm{Ag}^{+}$, as shown in Figure 11 . 


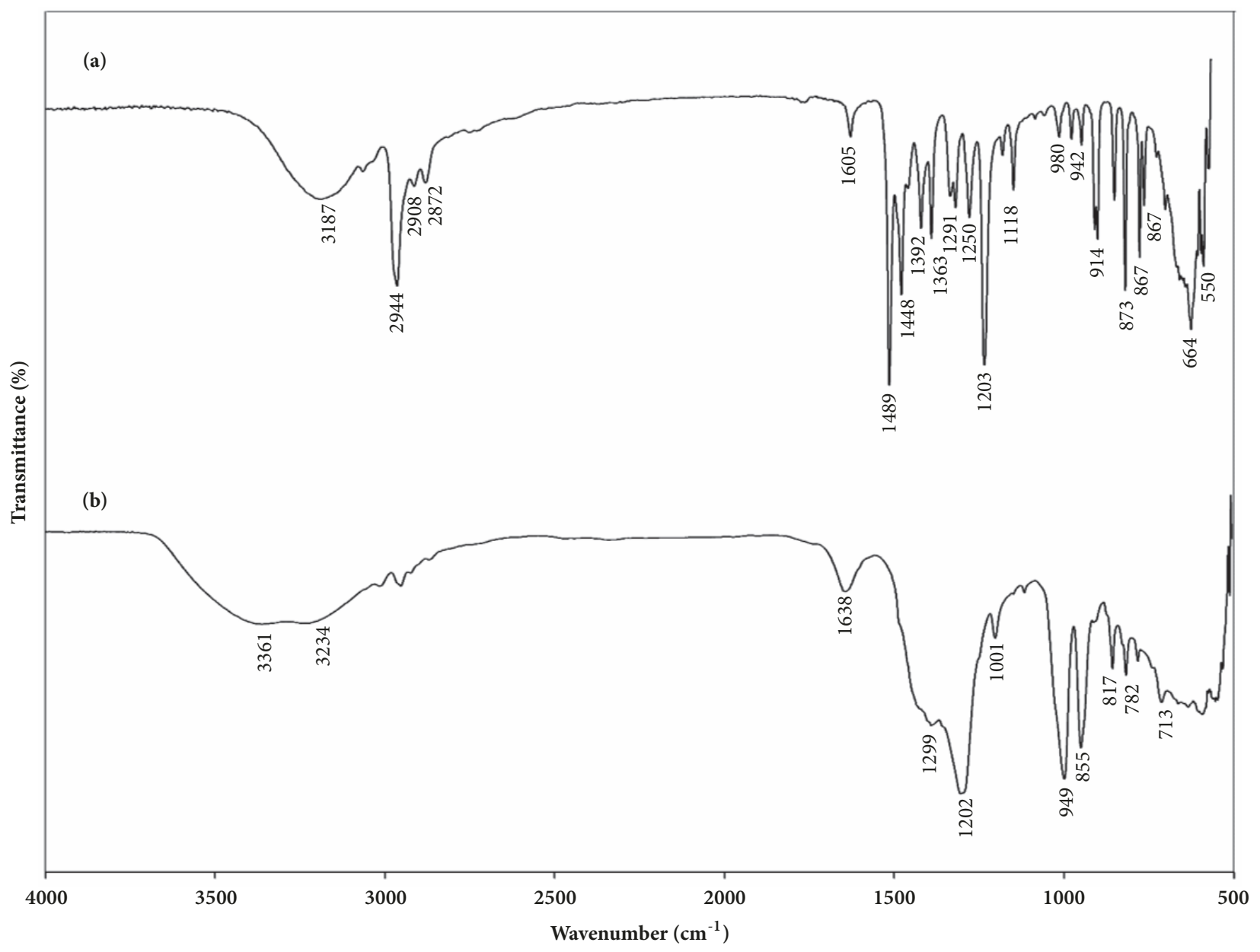

Figure 9: FTIR spectra of (a) $\mathrm{H}_{8} \mathrm{~L}$ and (b) $\mathrm{Cd}^{2+}-\mathrm{H}_{8} \mathrm{~L}$.

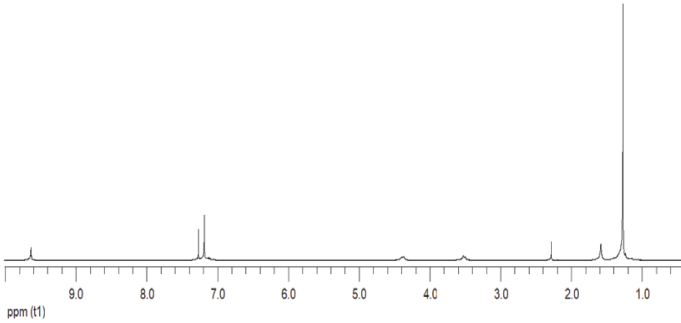

(a)

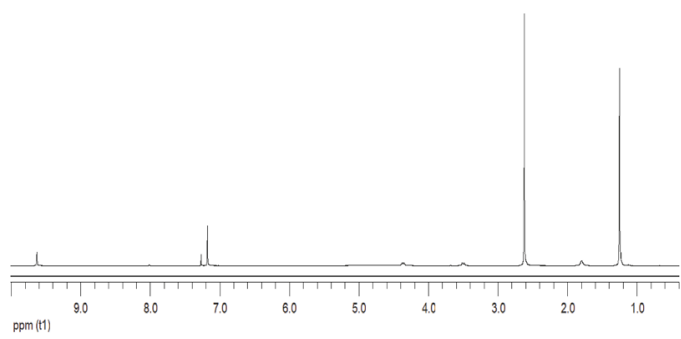

(b)

Figure 10: ${ }^{1} \mathrm{H}$ NMR spectra of (a) $\mathrm{H}_{8} \mathrm{~L}$ at $25^{\circ} \mathrm{C}$ in $\mathrm{CDCl}_{3}$ and (b) Cd-H8L at $25^{\circ} \mathrm{C}$ in $\mathrm{CDCl}_{3}$ at $400 \mathrm{MHz}$.

\section{Conclusions}

The host-guest extraction and/or complexation of divalent heavy metal cations and silver by $\mathrm{H}_{8} \mathrm{~L}$ and its ethyl ester host was investigated by changing various experimental parameters. The effect of the organic solvent on the extraction procedure was examined. In the solvents, the affinity of $\mathrm{H}_{8} \mathrm{~L}$ to bind transition metal cations was found to be much higher in the case of $\mathrm{Cd}^{2+}$ and $\mathrm{Ni}^{2+}$ when ammonia was used as the aqueous phase. The results from the extraction study suggested that, in the case of ammonia, the ratio of the extracted species is 2:1 $\left(\mathrm{H}_{8} \mathrm{~L}\right.$ :metal $)$, whereas in the presence of ethylene diamine instead of ammonia, the composition of the extracted species is $1: 1$, indicating selectivity towards tetrahedral type metal ions. The ester- $\mathrm{H}_{8} \mathrm{~L}$ compounds were found to be not effective for the extraction of transition metal cations under the present reaction conditions. The extraction behavior of the metal ions was closely related to the $\mathrm{pH}$ at equilibrium and the matrix and/or medium (i.e., ammonia or amine) of the aqueous solution and organic phase. 


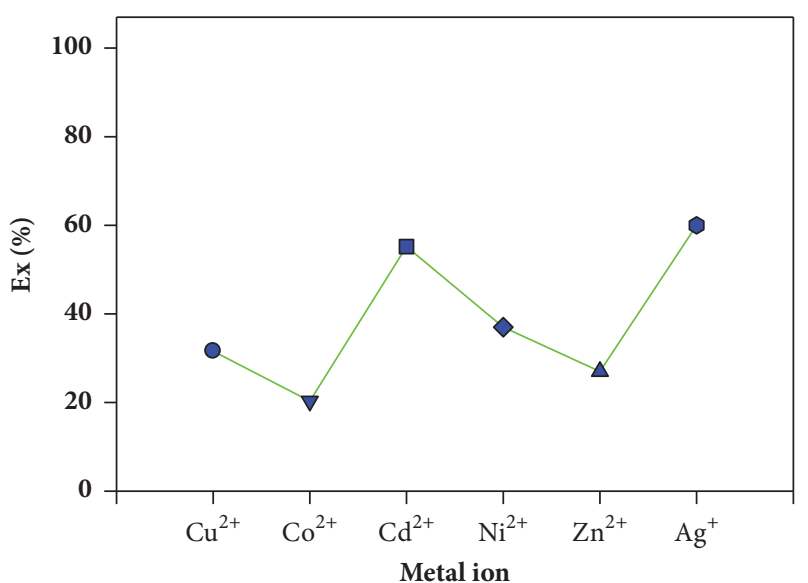

FIGURE 11: Metal ions percentage extraction (E\%) at $\mathrm{pH} 11.5$ by $\mathrm{H}_{8} \mathrm{~L}-$ ester. $\mathrm{O} / \mathrm{A}=1 ; \mathrm{T}=25^{\circ} \mathrm{C}$.

\section{Data Availability}

The data used to support the findings of this study are available from the corresponding author upon request.

\section{Conflicts of Interest}

The authors declare no conflicts of interest.

\section{References}

[1] V. Böhmer and J. Vicens, "Special Calixarenes, Synthesis and Properties," in Calixarenes: A Versatile Class of Macrocyclic Compounds, vol. 3 of Topics in Inclusion Science, pp. 39-62, Springer Netherlands, Dordrecht, 1990.

[2] C. D. Gutsche, "Calixarenes," The Royal Society of Chemistry, Cambridge, p. 181, 1989.

[3] K. Ohto, M. Yano, K. Inoue et al., "Effect of coexisting alkaline metal ions on the extraction selectivity of lanthanide ions with calixarene carboxylate derivatives," Polyhedron, vol. 16, no. 10, pp. 1655-1661, 1997.

[4] N. N. M. Yusof, Y. Kikuchi, and T. Kobayashi, "Predominant hosting lead(II) in ternary mixtures of heavy metal ions by a novel of diethylaminomethyl-calix[4]resorcinarene," International Journal of Environmental Science and Technology, vol. 11, no. 4, pp. 1063-1072, 2014.

[5] N. N. M. Yusof, Y. Kikuchi, and T. Kobayashi, "Ionic imprinted calix [4] resorcinarene host for $\mathrm{Pb}$ (II) adsorbent using diallylaminomethyl-calix[4]resorcinarene copolymer," Chemistry Letters, vol. 42, no. 10, pp. 1119-1121, 2013.

[6] M. Martínez-Aragón, E. Goetheer, and A. de Haan, "Host-guest extraction of immunoglobulin G using calix[6]arenas," Separation and Purification Technology, vol. 65, no. 1, pp. 73-78, 2009.

[7] T. Oshima, M. Goto, and S. Furusaki, "Complex formation of cytochrome $\mathrm{c}$ with a calixarene carboxylic acid derivative: A novel solubilization method for biomolecules in organic media," Biomacromolecules, vol. 3, no. 3, pp. 438-444, 2002.

[8] R. Ludwig, "Calixarenes in analytical and separation chemistry," Fresenius' Journal of Analytical Chemistry, vol. 367, no. 2, pp. 103-128, 2000.
[9] C. D. Gutsche, B. Dhawan, K. H. No, and R. Muthukrishnan, "Calixarenes. 4. The Synthesis, Characterization, and Properties of the Calixarenes from p-tert-Butylphenol," Journal of the American Chemical Society, vol. 103, no. 13, pp. 3782-3792, 1981.

[10] C. D. Gutsche and K. C. Nam, "Calixarenes. 22. Synthesis, Properties, and Metal Complexation of Aminocalixarenes," Journal of the American Chemical Society, vol. 110, no. 18, pp. 6153-6162, 1988.

[11] X. Chen, R. A. Boulos, A. D. Slattery, J. L. Atwood, and C. L. Raston, "Unravelling the structure of the C60 and p-Butcalix[8] arene complex," Chemical Communications, vol. 51, no. 57, pp. 11413-11416, 2015.

[12] J. L. Atwood, L. J. Barbour, M. W. Heaven, and C. L. Raston, "Controlling van der Waals Contacts in Complexes of Fullerene C60," Angewandte Chemie International Edition, vol. 42, no. 28, pp. 3254-3257, 2003.

[13] C. Geraci, G. Chessari, M. Piattelli, and P. Neri, "Cation encapsulation within a ten-oxygen spheroidal cavity of conformationally preorganized 1,5-3,7-calix[8]bis-crown-3 derivatives," Chemical Communications, no. 10, pp. 921-922, 1997.

[14] C. Redshaw, "Coordination chemistry of the larger calixarenes," Coordination Chemistry Reviews, vol. 244, no. 1-2, pp. 45-70, 2003.

[15] T. Kajiwara, N. Iki, and M. Yamashita, "Transition metal and lanthanide cluster complexes constructed with thiacalix[n]arene and its derivatives," Coordination Chemistry Reviews, vol. 251, no. 13-14, pp. 1734-1746, 2007.

[16] R. Ludwig and N. T. K. Dzung, "Calixarene-based molecules for cation recognition," Sensors, vol. 2, no. 10, pp. 397-416, 2002.

[17] C. J. Liu, J. T. Lin, S. H. Wang, J. C. Jiang, and L. G. Lin, "Chromogenic calixarene sensors for amine detection," Sensors and Actuators B: Chemical, vol. 108, no. 1-2, pp. 521-527, 2005.

[18] R. M. Izatt, J. D. Lamb, R. T. Hawkins, P. R. Brown, S. R. Izatt, and J. J. Christensen, "Selective M+-H+ Coupled Transport of Cations through a Liquid Membrane by Macrocyclic Calixarene Ligands," Journal of the American Chemical Society, vol. 105, no. 7, pp. 1782-1785, 1983.

[19] S. R. Izatt, R. T. Hawkins, J. J. Christensen, and R. M. Izatt, "Cation Transport from Multiple Alkali Cation Mixtures Using a Liquid Membrane System Containing a Series of Calixarene Carriers," Journal of the American Chemical Society, vol. 107, no. 1, pp. 63-66, 1985.

[20] L. Mutihac and R. Mutihac, "Liquid-liquid extraction and transport through membrane of amino acid methylesters by calix[n]arene derivatives," Journal of Inclusion Phenomena and Macrocyclic Chemistry, vol. 59, no. 1-2, pp. 177-181, 2007.

[21] S. Ayata and M. Merdivan, "P-tert-Butylcalix[8]arene loaded silica gel for preconcentration of uranium(VI) via solid phase extraction," Journal of Radioanalytical and Nuclear Chemistry, vol. 283, no. 3, pp. 603-607, 2010.

[22] L. N. Puntus, A.-S. Chauvin, S. Varbanov, and J.-C. G. Bünzli, "Lanthanide complexes with a calix[8] arene bearing phosphinoyl pendant arms," European Journal of Inorganic Chemistry, no. 16, pp. 2315-2326, 2007.

[23] G. Suganthi, C. Meenakshi, and V. Ramakrishnan, "Molecular recognition of 1,5 diamino anthraquinone by p-tert-butylcalix(8) arene," Journal of Fluorescence, vol. 20, no. 5, pp. 1017$1022,2010$.

[24] S. Erdemir, M. Bahadir, and M. Yilmaz, "Extraction of carcinogenic aromatic amines from aqueous solution using calix[n] arene derivatives as carrier," Journal of Hazardous Materials, vol. 168, no. 2-3, pp. 1170-1176, 2009. 
[25] I. Yoshida, S. Fujii, K. Ueno, S. Shinkai, and T. Matsuda, “ Solvent Extraction of Copper(II) Ion with ," Chemistry Letters, vol. 18, no. 9, pp. 1535-1538, 1989.

[26] E. Tashev, M. Atanassova, S. Varbanov et al., "Synthesis of octa(1,1,3,3-tetramethylbutyl)octakis(dimethylphosphinoylmethyleneoxy) ca lix [8] arene and its application in the synergistic solvent extraction and separation of lanthanoids," Separation and Purification Technology, vol. 64, no. 2, pp. 170-175, 2008.

[27] E. Makrlík, P. Vaňura, and P. Selucký, "Solvent extraction of europium trifluoromethanesulfonate into nitrobenzene in the presence of p-tert-butylcalix[6]arene and p-tertbutylcalix[8]arene," Journal of Radioanalytical and Nuclear Chemistry, vol. 287, no. 1, pp. 277-280, 2011.

[28] F. Sansone, M. Fontanella, A. Casnati et al., "CMPO-substituted calix[6]- and calix[8]arene extractants for the separation of An3+/Ln3+ from radioactive waste," Tetrahedron, vol. 62, no. 29, pp. 6749-6753, 2006.

[29] R. Pathak and G. N. Rao, "Synthesis and metal sorption studies of p-tert-butylcalix[8]arene chemically bound to polymeric support," Analytica Chimica Acta, vol. 335, no. 3, pp. 283-290, 1996.

[30] Md. Hasan Zahir, "Synthesis and Characterization of Trivalent Cerium Complexes of p-tert-Butylcalix[4,6,8]Arenes: Effect of Organic Solvents," Journal of Chemistry, vol. 2013, pp. 1-9, 2013.

[31] Y. Masuda and Md. H. Zahir, "The host-guest extraction chemistry of lighter lanthaniod (III) metal ions with p-tbutylcalix[6]arene from the ammonia alkaline solution in presence of succinic acid," Analytical Sciences, vol. 17, pp. a483a486, 2001.

[32] A. K. De, "Environmental Chemistry, New age international Ltd," Inorganic Chemistry and Analysis through Problems and Exercises, pp. 80-81, 2005.

[33] S. Petit, G. Pilet, D. Luneau, L. F. Chibotaru, and L. Ungur, "A dinuclear cobalt(ii) complex of calix[8]arenes exibiting strong magnetic anisotropy," Journal of the Chemical Society, Dalton Transactions, no. 40, pp. 4582-4588, 2007.

[34] P. Thuéry and M. Nierlich, "The first metal complex of an acyclic hexaphenol: structure of the binuclear complex of uranyl ions with an analogue of p-tert-butylcalix[6]arene," Journal of the Chemical Society, Dalton Transactions, no. 9, pp. 1481-1482.

[35] E. Akceylan, M. Bahadir, and M. Yilmaz, "Removal efficiency of a calix[4]arene-based polymer for water-soluble carcinogenic direct azo dyes and aromatic amines," Journal of Hazardous Materials, vol. 162, no. 2-3, pp. 960-966, 2009.

[36] C. J. Pouchert, The Aldrich library of IR spectra, Aldrich Chemical Company, Inc., 3rd edition.

[37] G. M. L. Consoli, F. Cunsolo, M. Piattelli, and P. Neri, "Study on the esterification of p-tert-butylcalix[8]arene," The Journal of Organic Chemistry, vol. 61, no. 6, pp. 2195-2198, 1996. 

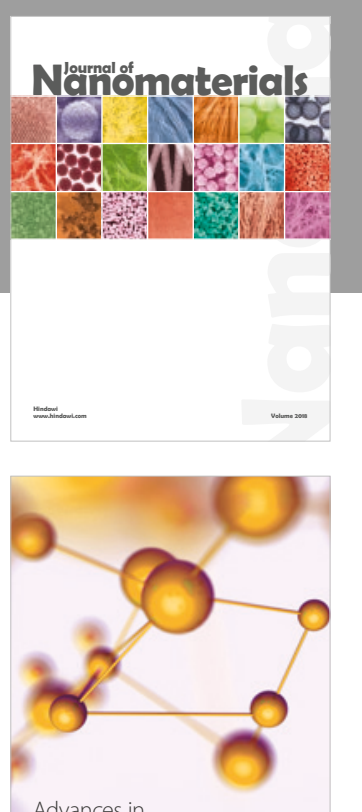

Physical Chemistry
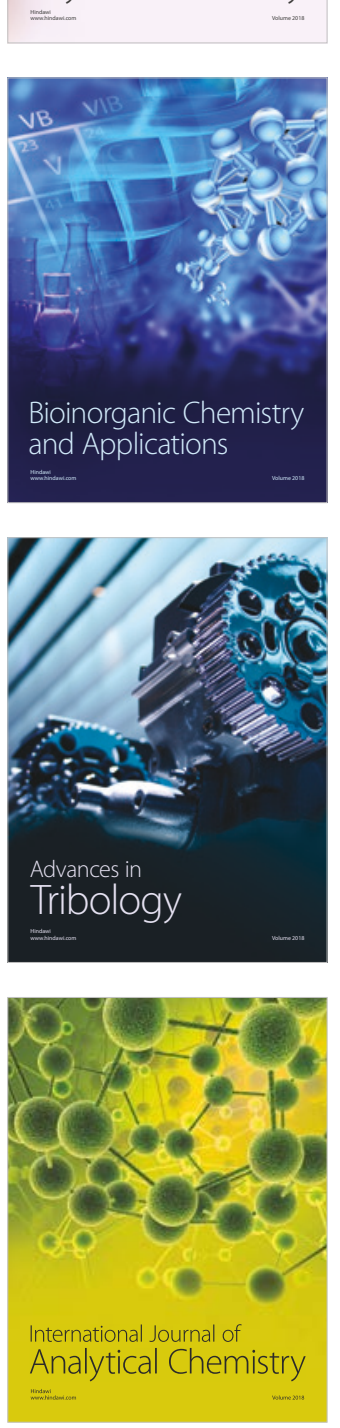

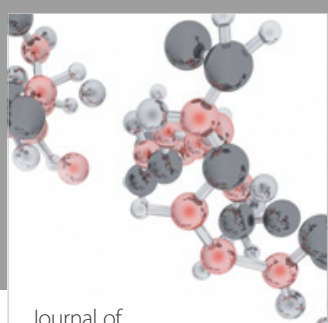

Analytical Methods

in Chemistry

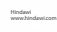

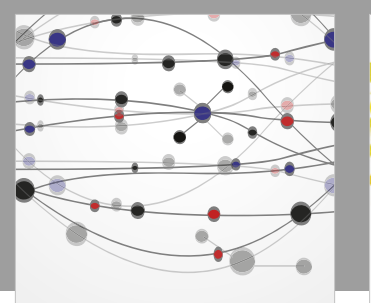

The Scientific World Journal

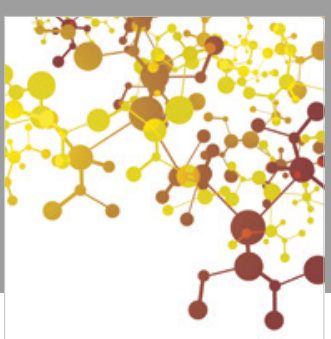

Journal of

Applied Chemistry
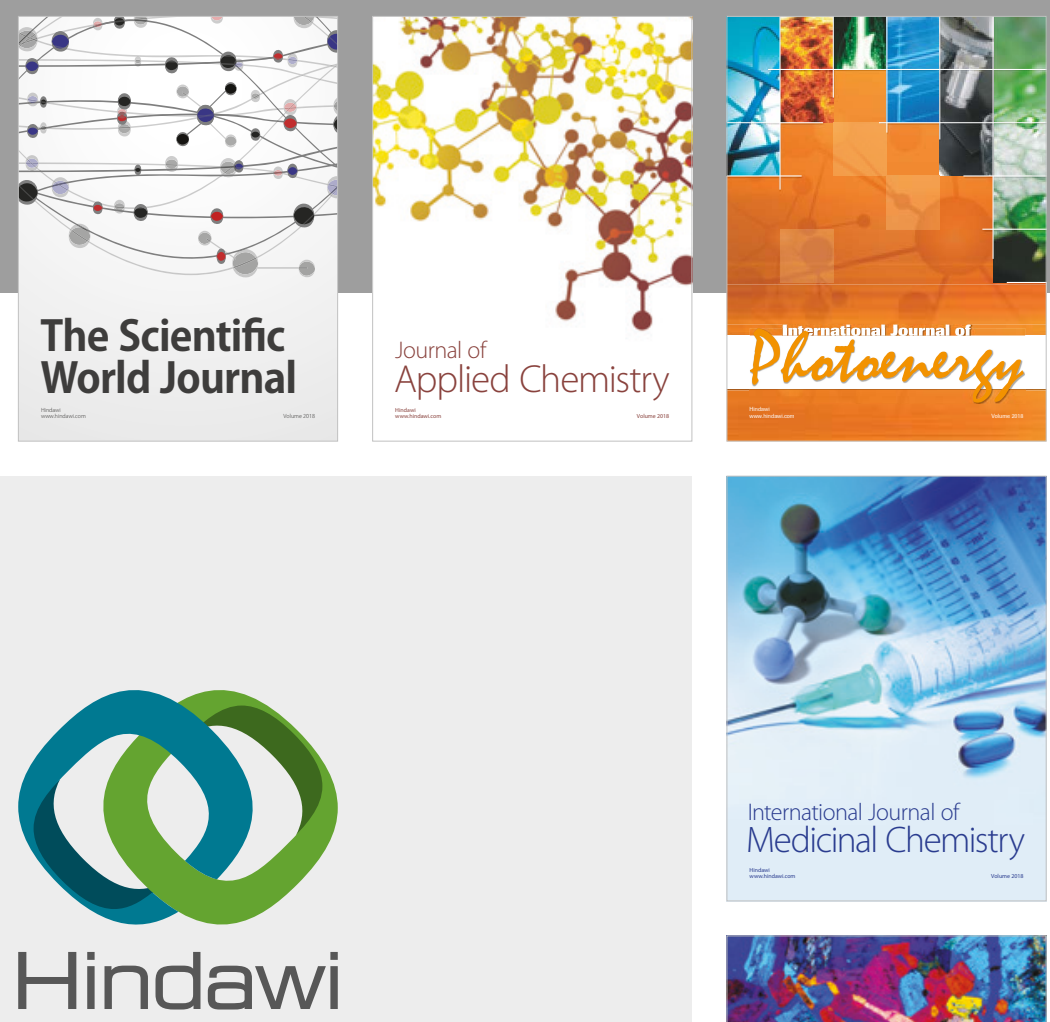

Submit your manuscripts at

www.hindawi.com
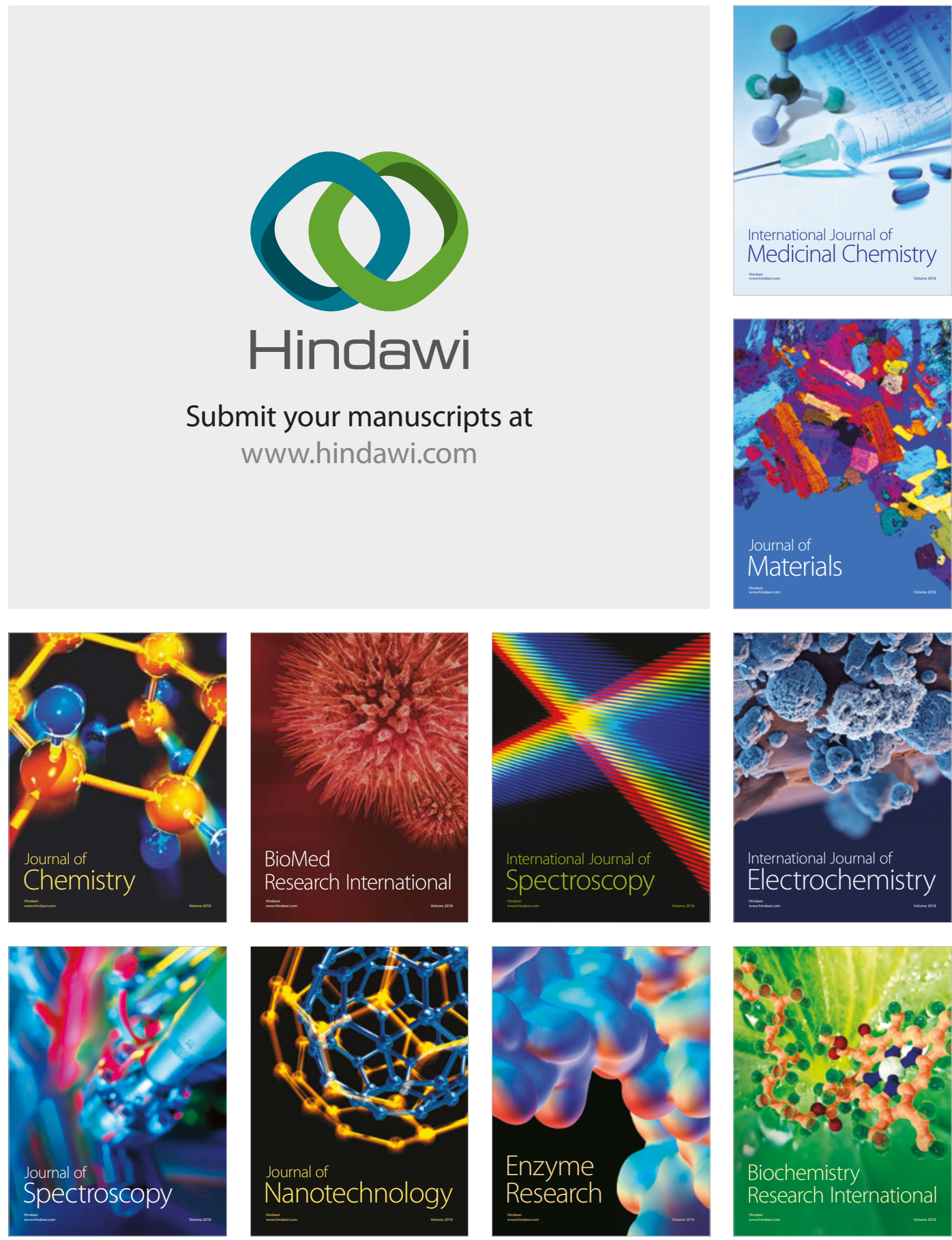
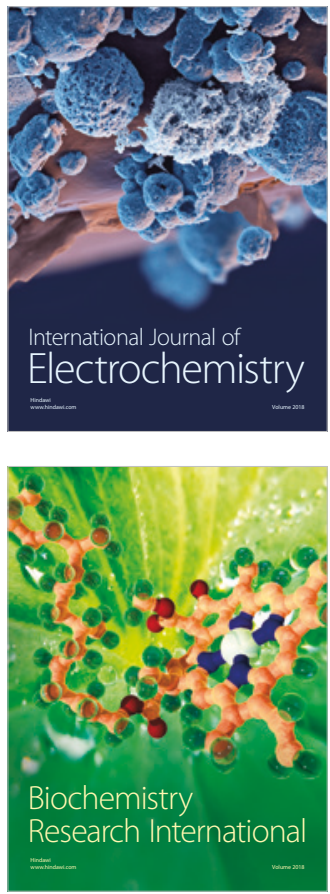